\title{
2. AESTHETICS AND TRUTH IN NIETZSCHE AND ADORNO
}

Estetika a pravda u Nietzscheho a Adorna

\section{Marcus Zagorski}

\section{Abstract}

This article presents a summary and analysis of Friedrich Nietzsche's early essay 'On Truth and Lies in a Nonmoral Sense' and argues that it is fundamentally an appeal to creativity. Although Nietzsche's essay is informed by his metaphysics and epistemology, it is essentially about aesthetics. I briefly consider Nietzsche's aesthetics against two trends in the history of the discipline-aesthetics as the philosophy of art, and aesthetics as the general study of perception-and align Nietzsche's work with one of those trends. Along the way, Nietzsche's conception of truth is examined and compared with other conceptions of truth in the realm of art theory, and his aesthetics is shown to be most relevant for a poetics of living, that is, for a life of creativity.

Táto štúdia predstavuje súhrn a analýzu ranného diela Friedricha Nietzscheho 'O pravdě a Iži ve smyslu nikoliv morálním' a tvrdí, že sa zo zásady apeluje na kreativitu. Napriek tomu, že Nietzscheho esej vyplýva z jeho metafyziky a epistemológie, je $v$ podstate $o$ estetike. Krátko som rozobral Nietzscheho estetiku cez prizmu dvoch trendov $v$ histórii disciplíny - estetiku, ako 
filozofiu umenia a estetiku, ako všeobecne štúdium vnímania - a zosynchronizoval Nietzscheho dielo $s$ jedným z týchto trendov. $V$ priebehu článku sa venujem aj Nietzscheho koncepcii pravdy, ktorá je skúmaná a porovnávaná $s$ inými koncepciami právd $v$ ríši teórií umenia. Jeho estetika je preukázatel'ne dôležitá pre životnú poetiku a tým aj pre živost' kreativity.

\section{Keywords:}

Nietzsche, aesthetics, truth, Adorno,

Nietzsche, estetika, pravda, Adorno.

„between subject and object there is no causality, no correctness, and no expression; there is, at most, an aesthetic relation" 25

[,,medzi subjektom a objektom nie je kauzalita, nie je správnost', ani žiaden výraz; existuje nanajvýš estetický vzt'ah"].

Despite Nietzsche's emphasis on aesthesis in the above quotation, we might read his assertion as more relevant, ultimately, to poiesis. There is a seeming paradox in such a reading: production (poiesis) is

\footnotetext{
25 NIETZSCHE, Friedrich. 1979. 'On Truth and Lies in a Nonmoral Sense', trans. Daniel Breazeale, in Philosophy and Truth: Selections from Nietzsche's Notebooks of the early 1870s. New Jersey: Humanities Press, 1979. 86. Nietzsche's original appears as 'Ueber Wahrheit und Lüge im aussermoralischen Sinne', in Nietzsche Werke: Kritische Gesamtausgabe, Giorgio Colli and Mazzino Montinari, eds., vol. III/2. Berlin: Walter de Gruyter, 1973. 367-384.
} 
generally thought to precede perception (aesthesis), and I am suggesting that poiesis here follows from aesthesis. To the extent that aesthetic theories always make claims to truth and become prescriptive, they already direct the course of production and allow poiesis to follow from aesthesis; but Nietzsche's essay 'On Truth and Lies in a Nonmoral Sense', from which the opening quote is taken, attempts more than a dismantling of truth, for behind his criticism of truth lies his analysis of human nature as essentially creative. The creative drive is expressed as we refashion the world through metaphor, and aesthesis becomes the wellspring of poiesis. But this is to begin where Nietzsche ends, and it is worthwhile to trace the steps that led to his conclusions. Why is this worthwhile? Because for a philosophy that advocates the cultivation of creativity as most fundamentally human, it is itself an extraordinarily creative answer to the questions from which it began. $A$ summary of Nietzsche's essay forms the first section of my article. I then consider the implications of his essay upon aesthetics, differentiating between a narrower understanding of aesthetics as the philosophy of art and a broader understanding of aesthetics as the study of 
perception. Finally, I will suggest that Nietzsche's essay is ultimately most relevant to poiesis, and that his subsequent creative work might be taken as proof of my interpretation.

\subsection{SUMMARIZING NIETZSCHE'S ESSAY}

Nietzsche's aesthetic ideas are closely related to his ideas about metaphysics and epistemology. Although none of these three fields are developed thoroughly in the his essay, their interrelation is apparent from the opening paragraph. Nietzsche begins with an account of the invention of knowing as a lie perpetrated by the human intellect: painfully aware of its own insignificance in the cosmos, the intellect makes claims to understand a vastness that is beyond human, and this understanding imbues it with a sense of superiority. This, says Nietzsche, 'was the most arrogant and mendacious minute of "world history", but it was only minute'. I cite this passage for its reference to Hegel (placed in quotation marks by Nietzsche), for the role of truth in Hegel's aesthetics will be discussed later in this article.

Nietzsche continues by arguing that the belief that man possesses knowledge results in pride, and this 
enfolds man and deceives him about the value of his existence. Such deception is employed by the intellect as a means for the preservation of the individual, for the individual quails when faced with his insignificance. Yet, in a state where man's highly developed faculty of dissimulation has immersed him completely in illusion, he nonetheless has a drive for truth. Nietzsche's next task is to determine how this drive for truth arises, and to answer this he turns to another side of human character: our shared existence in a community. Although individual preservation is effected by dissimulation, there is also a need for man to exist socially. To facilitate communal existence, man invents binding linguistic designations for things in the world, and gives these the function of truths. But this raises the question of the extent to which linguistic conventions called 'truths' are congruent with the things they designate-how adequate is their expression of reality? For Nietzsche, the linguistic conventions we consider truths are only arbitrary metaphors: a transference to sound (language) of that which strikes us as an image resulting from a nerve stimulus. These metaphors are not true expressions, and 
we possess truths only to the extent that we forget the metaphorical nature of expression.

Closer to an understanding of truth, Nietzsche now introduces the important term 'concept' into the essay, which plays a key role in his criticism of man's creation of a world constructed of truths. Concepts are formed from words when words cease to serve as reminders of unique original experiences and are instead used to stand for similar but unequal things. A concept ignores what is individual and distorts it so that it conforms to a 'kind'; such concepts, according to Nietzsche's critique, represent only our relationship to nature and not nature-in-itself. But even if we concede this and are willing to see truths as mere linguistic conventions, and concepts as outgrowths of those conventions, we have not yet determined from where the drive for truth originated. In Nietzsche's analysis in this early essay, this drive comes from man's desire to construct a regulated and knowable world from the irregular and unpredictable world that surrounds him. By limiting unique sense impressions through the formation of concepts and constructing a system of these concepts into which can be placed any new experience, man 
regulates new experiences by subjugating them to his scheme of concepts. When he finds that new experiences can then be explained by his system of concepts, he believes he has found the truth in things, forgetting that he has merely found a truth that he himself created. And thus 'what the investigator of such truths is seeking is only the metamorphosis of the world into man'.

It is precisely because man has forgotten that he created a world which conforms to his expectations that he lives at peace in a world which conforms to his expectations. But man is the creator; and because he has created in response to that which is perceived, he obtains only an aesthetic relationship to objects. The reader should note that the implications for aesthetics (conceived broadly) are here profound: because this world that man has created is a transferred expression of perception, everything in the world is determined by an aesthetic relation. Thus when one speaks of finding the essence of things, one has in fact found only an essence created by oneself, according to the capacity of our perceptual faculties. And this leads Nietzsche, already in 
1873 , to a condemnation of science, which has taken over from language the labor of constructing concepts.

Essential to Nietzsche's early essay is his belief that 'the drive toward the formation of metaphors is the fundamental human drive'. And, fortunately for Nietzsche, this drive is not subdued by the creation of a knowable world of concepts, for it finds new channels for its activity in myth and art. This drive continually brings forth new transferences and 'continually manifests an ardent desire to refashion the world', that it might tear down conceptual conventions and recapture the richness and immediacy of original perception. Because the creation of metaphor is fundamentally human, man is happiest when he allows himself to be deceived. The intellect is freed when it is able to deceive without injuring, and 'it is released from its former slavery' to the restrictive system of concepts. By advocating the cultivation of this fundamental human drive, Nietzsche celebrates creativity and refuses the alternative of constraining conventions and emasculated experiences represented by concepts, which shackle creativity to the service of mere comfort and preservation. Man should instead attune his creativity to ever new experience, 
Nietzsche says, for by 'shattering and mocking the old conceptual barriers he may at least correspond creatively to the impression of the powerful present intuition'. Nietzsche concludes his short essay with a comparison of two types of man-the rational (inartistic) and the intuitive (artistic)-and he clearly favors the latter. Both types desire to rule over life, but the rational man does this by means of foresight, prudence, and regularity, and he succeeds only in avoiding misfortune without ever gaining happiness for himself. The intuitive man rules over life by disregarding his principal needs and 'as an "overjoyed hero", counting as real only that life which has been disguised as illusion and beauty'; as his power grows, a culture may form in which art can master life.

\subsection{AESTHETIC IMPLICATIONS}

Emerging from this early essay of Nietzsche's is the revaluation of truth as lie, and lie as the only possible truth. $^{26}$ Lies-as metaphor, art, or myth-are true

\footnotetext{
26 Nietzsche's explicit use of the term 'revaluation' became a feature of his writing more than a decade after 'Truth and Lies' was written, and the similarity of the ideas behind this early essay and his later books is striking.
} 
because they accept illusion as illusion; truths, on the other hand, have forgotten their origin in metaphor and subsequent growth as mere linguistic convention. In other words: any claim to truth is a lie because it presumes that truth is more than a creative metaphor. Behind both truth and lie is a drive to transfer sense perception to other spheres, so that aesthesis forms the single source from which they spring. This would seem to suggest that Nietzsche's essay could bear fruit if applied to the field of aesthetics; but its effects will differ according to how the term 'aesthetics' is understood. In the introductory paragraph of this article I stated that, in my consideration of the aesthetic implications of Nietzsche's essay, I would differentiate between a narrower understanding of aesthetics as the philosophy of art and a broader understanding of aesthetics as the study of perception. Such a distinction is relevant to the aesthetic interpretation of the essay because Nietzsche's ideas can be applied differently to these two meanings of the term 'aesthetics'. I will consider first his ideas as applied to the narrower understanding of the term as the philosophy of art. 


\subsection{AESTHETICS AS THE PHILOSOPHY OF ART}

Even those who are critical of the narrower conception of aesthetics recognize its tremendous significance in shaping the discipline over the past two centuries. Wolfgang Welsch has argued that aesthetics, as defined narrowly in philosophical encyclopedias and by philosophers in the discipline itself, would be more accurately named as 'artistics': it is an 'explication of art with particular attention to beauty'. And as such, it does not respect the much more general 'science of sensuous cognition' established by Baumgarten and for which he coined the term 'aesthetics'. ${ }^{27}$ Aesthetics in the narrow sense means only the philosophy of art, and Welsch notes that such a meaning was introduced by Kant, developed in Hegel, and is still preferred by many philosophers today. But Nietzsche's essay should alert us to an understanding of aesthetics that goes beyond mere 'artistics': he makes use of a much broader conception of aesthetics-something that is not a

27 WELSCH, Wolfgang Welsch. 1997. 'Aesthetics Beyond Aesthetics', in Proceedings of the XIIIth International Congress of Aesthetics, vol. III: Practical Aesthetics in Practice and Theory, ed. Martti Honkanen, Helsinki 1997. 18-37. Available online at www2.uni jena.de/welsch/ (rev. 1999), accessed 1 June 2014. 
philosophy of the beautiful, but a philosophy of perception. And his ideas, particularly his revaluation of truth as lie, can be applied to the more limited use of aesthetics as a means of critique.

When aesthetics, narrowly conceived as artistics, establishes criteria of judgment, makes claims to truth, and dictates the manner of production, it passes over into something false-an illusion that refuses to recognize itself as illusion. Aesthetics is in danger when it attempts to enter the realm of truth. And yet truth is necessarily the domain of the philosophy of art, for the only truth that is true, according to Nietzsche, is found in the illusion of art. ${ }^{28}$ Can this be resolved? A possible answer might suggest that if truth in art results from treating illusion as illusion, and aesthetics is the philosophy of art, then aesthetics must recognize its topic as purposeful illusion and that it is itself another layer of metaphor upon that illusion. But the philosophy of art has had, at times, a very different agenda.

'In art we are dealing not with a merely pleasurable or useful plaything, but with...an unfolding of

\footnotetext{
28 This is stated explicitly in Nietzsche's notes for additional sections appended to the essay: 'art treats illusion as illusion; therefore it does not wish to deceive; it is true'. Philosophy and Truth, 96.
} 
truth'. This quote from Hegel's Aesthetics is used by Adorno to head the introduction of his Philosophie der neuen Musik, a book the author himself considered to be 'definitive for everything that [he] wrote about music thereafter'. ${ }^{29}$ The quote from Hegel has been interpreted by Stephen Hinton as a motto for Adorno's entire approach to aesthetics ${ }^{30}$ and Hinton also notes that Nietzsche was Adorno's nearest predecessor. But I bring Adorno into this article to serve as Nietzsche's antipode-an opposition which is apparent in Adorno's aesthetic 'motto' that equates art with truth. For although Nietzsche, too, had made the equation between art and truth, the truth in art that Adorno apprehends is no illusion.

The unfolding of truth that Adorno would claim for art is manifested in art's relation to history, and a disclosure of the state of history (and the 'state of the

29 'Die Philosophie der neuen Musik ... war verbindlich für alles, was ich danach irgend über Musik schrieb'. See ADORNO, Theodor W. 1977. 'Wissenschaftliche Erfahrungen in Amerika', Gesammelte Schriften 10. Suhrkamp: Frankfurt a. M., 1977. 702-738, here 719. Translations are my own unless noted otherwise. See also, ADORNO. Theodor W. 1975. Philosophie der neuen Musik, Gesammelte Schriften 12. Frankfurt a.M.: Suhrkamp, 1975.

30 See HINTON, Stephen 1998. 'Adorno's Philosophy of Music', in The Encyclopedia of Aesthetics, ed. Michael Kelly. New York: Oxford University Press, 1998. vol. 1, 26. 
spirit' in a Hegelian geschichtsphilosophische sense) is reflected in music by its 'material'. This concept of material is fundamental to Adorno's music aesthetics; it first appears in his writings as early as the 1920s, and it is gradually modified over the following five decades, appearing finally in the 'Materialbegriff' section of the late Ästhetische Theorie. ${ }^{31}$ The concept is characterized by Adorno in his Philosophie der neuen Musik thusly:

The assumption of a historical tendency of musical material contradicts the traditional conception of the material of music. It is defined with recourse to physics, or perhaps music psychology, as the sum of sounds that have ever been available to a composer. But compositional material is as different from this as is language from the stock of its sounds. It does not just increase or decrease with the course of history. All its specific traits are marks of the historical process. ${ }^{32}$

31 The history of Adorno's use of the term is beyond the scope of this paper, but the reader is referred to a concise discussion in BORIO, Gianmario. 1994. 'Material-zur Krise einer musikästhetischen Kategorie', in Darmstädter Beiträge zur Neuen Musik 20, eds. Gianmario Borio and Ulrich Mosch. Mainz: Schott, 1994. 108-118; see also DAHLHAUS, Carl. 1978. 'Adornos Begriff des musikalischen Materials', Schönberg und Andere: Gesammelte Aufsätze zur Neuen Musik, Mainz: Schott. 1978. 336-342.

32 'Die Annahme einer geschichtlichen Tendenz der musikalischen Mittel widerspricht der herkömmlichen Auffassung vom Material der 
We should not overlook, embedded within this concept of musical material, a philosophy of history that is used to establish the 'truth' behind Adorno's aesthetic preferences. The Materialbegriff serves Adorno as a means to prescriptive aesthetics, for it enables him to judge music (and compositional method) according to the irrefutable standard of truth as determined by a correspondence with the Hegelian 'state of the spirit'. But it is just this claim, in Nietzsche's analysis, that would reveal the lie in Adorno's professed truth. Adorno's aesthetics refused to recognize itself as illusion-and only by acknowledging illusion as illusion could it claim to be true. Adorno could be said to belong to that same arrogant and mendacious minute of 'world history' into which Hegel was placed.

\subsection{AESTHETICS AS THE STUDY OF PERCEPTION}

However much the historical dimension of

Musik. Es wird physikalisch, allenfalls tonpsychologisch definiert, als Begriff der je für den Komponisten verfügbaren Klänge. Davon aber ist das kompositorische Material so verschieden wie die Sprache vom Vorrat ihrer Laute. Nicht nur verengt und erweitert es sich mit dem Gang der Geschichte. Alle seine spezifische Züge sind Male des geschichtlichen Prozesses.' ADORNO, Philosophie der neuen Musik, 38. 
Adorno's aesthetics opens up the door to the criticisms mentioned above, it is also the use of history that allows him to transcend aesthetics as mere 'artistics'. In the sections entitled 'On the Dialectics of Aesthetic Experience' and 'Universal and Particular' in the Draft Introduction of Aesthetic Theory, Adorno repeatedly states that a philosophical aesthetics must move beyond work-immanent analysis and consider also the social and historical elements present in the artwork. ${ }^{33}$ And Adorno's arguments are included in Welsch's call for an expanded understanding of aesthetics mentioned above-an understanding that respects Baumgarten's original meaning of the term. ${ }^{34}$ Aligning himself with Baumgarten, Nietzsche seems to advocate a broad conception of aesthetics in 'On Truth and Lies'. Nietzsche's assertion (which I have given as a lemma to this paper) that 'there is, at most, an aesthetic relation' between subject and object, should be read not as a philosophy of the beautiful but as a philosophy of perception-though Nietzsche surely would not have

33 ADORNO, Theodor W1997. Aesthetic Theory, trans. and ed. by Robert Hullot-Kentor. Minneapolis: University of Minnesota Press, 1997. 348-349.

34 See WELSCH, 'Aesthetics Beyond Aesthetics'. 
aspired to the 'science of sensuous cognition' intended by Baumgarten! If man has only this aesthetic relation to objects, then every subsequent construction-be it metaphorical, conceptual, truth, or lie-is founded ultimately upon perception. In this respect one might say that for the Nietzsche of 'On Truth and Lies', everything is aesthetic.

Everything is aesthetic: the statement is as profound as it is simple. It is profound not for aesthetics, but rather for all other spheres of human activity because they all have their origins in aesthetic experience. In such a conception, aesthetics becomes something more like the study of genealogies, and it may be no coincidence that Nietzsche was an advocate of both of these methods of inquiry. Both methods are concerned with an investigation of origins, but in this early essay even the moral dimensions of truth and lie are considered and related to metaphors of perception.

\subsection{POIESIS}

But the mere fact that we perceive does not make us human. If Nietzsche had stopped at perception he would have had to ignore what he himself had become 
and was still becoming: writer, philosopher, poet, and artist. It is precisely these creative aspects of Nietzsche that inform perhaps the most essential point of the essay: his belief that the drive toward the formation of metaphors is the fundamental human drive, which one cannot for a single instant dispense with in thought, for one would thereby dispense with man himself'. ${ }^{35}$ As humans, we are driven to create metaphors that translate our perceptual experience; but we can choose to fall back upon conventions to express new experience, or we can cultivate the very conception of experience by fashioning new metaphors that 'correspond creatively to the impression of the powerful present intuition'. ${ }^{36}$ To fall back upon conventions is, for Nietzsche, not only to follow the herd but also to enslave ourselves to the lie of concepts, to divest the world of its richness, to stifle our fundamental drive, and to abandon any hope for happiness. And all the branches of Nietzsche's philosophy in this essay-metaphysics, epistemology, and aesthetics - are fed by the desire of a creative spirit to justify creativity as that which resists the impoverishment of life. Nietzsche's emphasis on

${ }^{35}$ NIETZSCHE, 'On Truth and Lies', 88-89. 
aesthesis is ultimately an appeal to poiesis and, therefore, an appeal to creativity.

\section{BIBLIOGRAPHY:}

ADORNO, Theodor W. 1997. Aesthetic Theory [Estetická Teória]. Trans. and ed. by Robert HullotKentor. Minneapolis:1997, University of Minnesota Press, p. 348-349.

ADORNO. Theodor W. 1975. Philosophie der neuen Musik, [Filozofia novej hudby]. In Gesammelte Schriften 12, Suhrkamp, Frankfurt a.M.: 1975, s.522-532.

ADORNO, Theodor W. 1977. Wissenschaftliche Erfahrungen in Amerika. In Gesammelte Schriften 10 [Vedecké skúsenosti v Amerike]. In Zobrané spisy 10 Suhrkamp, Frankfurt a. M.: 1977. s. 702-738.

BORIO, Gianmario. 1994. Material-zur Krise einer musikästhetischen Kategorie. In Darmstädter Beiträge zur Neuen Musik 20 [Materiál - ku kríze hudobnoestetickej kategórie]. In Darmstadtské príspevky k Novej hudbe 20. Eds. Gianmario Borio and Ulrich Mosch. Mainz: 1994.Schott, s. 108-118.

${ }^{36}$ NIETZSCHE, 'On Truth and Lies', 90. 
DAHLHAUS, Carl. 1978. Adornos Begriff des musikalischen Materials. Schönberg und Andere: Gesammelte Aufsätze zur Neuen Musik [Adornov pojem hudobného materiálu. Schönberg a kolektív]. In Zobrané state k Novej hudbe. Mainz: 1978,.Schott, s. 336-342.

HINTON, Stephen 1998. Adorno's Philosophy of Music [Adornova Filozofia hudby]. In The Encyclopedia of Aesthetics. ed. Michael Kelly. New York:1998, Oxford University Press,vol. 1, p. 25-29.

NIETZSCHE, Friedrich. 1979. On Truth and Lies in a Nonmoral Sense [O pravdě a lži ve smyslu nikoliv morálním]. trans. Daniel Breazeale. In Philosophy and Truth: Selections from Nietzsche's Notebooks of the early. New Jersey: 1979, Humanities Press, $870 p$.

NIETZSCHE, Friedrich. 1973. Ueber Wahrheit und Lüge im aussermoralischen Sinne. In Nietzsche Werke: Kritische Gesamtausgabe [O pravde a Iži v mimomorálnom zmysle. In Nietzscheho diela: Kritické súborné vydanie]. Giorgio Colli and Mazzino Montinari, eds., vol. III/2. Berlin:1973, Walter de Gruyter,p. 367384.

WELSCH, Wolfgang. 1997. Aesthetics Beyond Aesthetics [Estetika a Anestetika]. In Proceedings of the XIIlth International Congress of Aesthetics, vol. III: Practical Aesthetics in Practice and Theory. Ed. Martti Honkanen, Helsinki 1997, p. 18-37. Available online at www2.uni-jena.de/welsch/ (rev. 1999), accessed 1 June 2014. 


\section{Contact information:}

Marcus Zagorski, Dr., PhD. (USA), Comenius University, Bratislava,

E-mail: marcus.zagorski@uniba.sk 